\title{
ANALISIS KAPASITAS RUANG PARKIR PASAR SENTRAL KOTA MAJENE
}

\author{
Milawaty waris,ST.,MT.1* ${ }^{*}$ Irma ridhayani Tammabela,ST.,MT ${ }^{2}$ \\ 1. Prodi Teknik Sipil, Fakultas Teknik, Universitas Sulawesi Barat, Jl.Prof. Dr.H.Baharuddin Lopa, \\ Talumung Majene, 91412, Indonesia \\ *e-mail: mayla132@yahoo.com \\ 2. Prodi Teknik Sipil, Fakultas Teknik, Universitas Sulawesi Barat, J1.Prof.Dr.H.Baharuddin Lopa, \\ Talumung Majene, 91412, Indonesia \\ *e-mail: irmaridhayani@ymail.com
}

\begin{abstract}
Abstrak
Penelitian ini dilaksanakan di Pasar Sentral Kota Majene, Sulawesi Barat. Pasar Sentral Majene yang berlokasi di Kecamatan Banggae merupakan, pasar yang sering dikunjungi oleh berbagai kalangan karena menyediakan berbagai macam kebutuhan hidup.
\end{abstract}

Penelitian ini bertujuan (1) Mengetahui karakteristik parkir, (2) Menjelaskan tentang pengelolaan parkir (3) memberikan masukan alternatif tentang penataan ruang parkir serta pengelolaan retribusi parkir.

Metode yang digunakan dalam penelitian ini adalah survey lapangan dengan mencatat jenis kendaraan yang keluar masuk dalam area parkir. Pengambilan data yang digunakan dalam penelitian ini menggunakan 2 (dua) metode yaitu : 1). Metode penelitian lapangan (Field Research Method) yaitu pengamatan langsung pada lokasi untuk melihat kondisi fisik; 2) Metode Penelitian Kepustakaan (Library Research Method). Analisis data dilakukan dengan cara deskriptif dengan memberikan gambaran terhadap lokasi melalui identifikasi terhadap variabel-variabel antara lain analisis karakteristik parkir dan penataan ruang parkir yang dapat memberikan rasa aman dan nyaman.. Data dianalisis dengan menghitung besarnya jumlah kebutuhan parkir yang harus disediakan lahan parkir yang meliputi kapasitas parkir, volume parkir, akumulasi parkir, durasi parkir, tingkat penggunaan parkir, dan indeks parkir.

Hasil penelitian diperoleh tempat parkir yang dibutuhkan sebesar 1.171 tempat parkir untuk kendaraan transportasi. Pemeliharaan parkir perlu dilakukan oleh pemerintah untuk memperhatikan ruang parkir di Pasar Sentral Kota Majene dan diharapkan menjadi perencanaan strategis dalam pengaturan dan retribusi pengaturan parkir di pasar pusat Kota Majene dan pengelolaan parkir Hasil penelitian ini menunjukkan karakteristik parkir di Pasar Sentral Majene yang meliputi volume, akumulasi dan kapasitas parkir diperoleh bahwa: 1). Volume parkir jam puncak pembeli/pengunjung terjadi pada jam 10:00 sampai 14:00; 2). Akumulasi parkir puncak tertinggi terjadi pada hari minggu pukul 11.00-15.00 oleh pembeli/ pengunjung dengan akumulasi; 3) Kapasitas parkir tertinggi pada jam 10:00 sampai jam 14:00. Bentuk yang cocok untuk kegiatan parkir di pasar sentral Majene adalah bentuk parkir $90^{\circ}$ dan bentuk parkir sudut dengan kemiringan $45^{\circ}$. Demikian juga untuk konsep pola parkir dan penataannya dapat dibedakan atas : 1) parkir untuk pengunjung harus mudah dicapai dan dekat dengan jalan sebagai akses utama; 2). Parkir pengelola harus dipisahkan dengan parkir pengunjung; 3) parkir hendaknya dapat dipisahkan berdasarkan jenis kendaraan.

Kata kunci; karakterikstik parkir, penataan ruang parkir, Akumulasi parkir 


\section{Pendahuluan}

Seiring dengan meningkatnya pertumbuhan populasi dan ekonomi tinggi di daerah perkotaan, itu akan menghasilkan peningkatan kebutuhan fasilitas yang dibutuhkan oleh masyarakat seperti pusat bisnis, pendidikan, kantor dan perdagangan. Masalah parkir sangat penting untuk dikaji lebih dalam, karena hampir semua kegiatan di ruang terbuka membutuhkan fasilitas parkir. Tempat parkir yang dibutuhkan harus tersedia secara memadai. Karena semakin besar volume lalu lintas yang aktif baik meninggalkan atau menuju ke pusat kegiatan, semakin besar kebutuhan ruang parkir, jika tidak cukup kendaraan akan mengambil parkir

di sepanjang jalan di sekitar daerah itu, menyebabkan kekacauan. Jadi parkir di jalan raya (on street parking) harus diatur dan dibatasi dengan menyediakan ruang parkir sesuai kebutuhan [1].

Fasilitas parkir di pusat layanan, kantor, pusat perbelanjaan, restoran dan tempat kegiatan potensial lainnya karena generator lalu lintas pada umumnya belum menyelesaikan fasilitas parkir yang memadai sehingga ukuran badan jalan utama di sekitar kegiatan ini digunakan sebagai tempat parkir yang dapat -mengurangi lebar jalur terakhir menyeberang jalan raya [5]. Fasilitas parkir umum juga dapat berfungsi sebagai alat untuk mengendalikan lalu lintas. Untuk memenuhi kebutuhan ini, fasilitas parkir umum tertentu dapat disediakan di area tertentu yang dicoba sebagai kegiatan bisnis yang berdiri sendiri dengan biaya tertentu. Tidak dapat dipahami bahwa parkir adalah salah satu sumber pendapatan daerah, sehingga kebijakan parkir yang diambil juga harus diarahkan untuk meningkatkan PAD sejauh mungkin dengan tidak melupakan manfaat yang akan diperoleh oleh pengendara yang parkir di tempat itu [8] .

Pasar Sentral di Majene, berlokasi di Kec. Banggae sebagai ibukota Kabupaten Majene adalah pasar yang sering dikunjungi oleh berbagai kelompok karena menyediakan berbagai kebutuhan hidup sehingga berbagai masalah terjadi terutama pada sistem transportasi baik sarana maupun prasarana. Pasar Pusat Majene dibangun di atas lahan seluas $15.395 \mathrm{~m}^{2}$ yang terdiri dari $13.335 \mathrm{~m}^{2}$ yang digunakan untuk bangunan pasar dan area tanpa bangunan seluas $2.060 \mathrm{~m}^{2}$ yang digunakan untuk parkir dan sirkulasi. Pasar ini dikelilingi oleh empat jalan, yaitu di sebelah utara Jalan Kanjuha, di sebelah kanan pasar, di sebelah timur Jalan Lanto Dg. Pasewang berada di depan pasar, di sebelah selatan Jalan A Wahab Azasi di sebelah kiri pasar dan di sebelah barat Jalan Mayjend A. Azis Bustam berada di belakang Pasar.

Masalahnya adalah kondisi parkir di Kabupaten Majene sehingga mengoptimalkan biaya parkir yang diharapkan dapat meningkatkan kontribusi terhadap Pendapatan Asli Daerah (PAD). Membiayai pemerintah daerah dalam melaksanakan tugas-tugas pemerintah dan pembangunan selalu membutuhkan sumber pendapatan yang dapat diandalkan. Keberadaan otonomi daerah didorong untuk menjadi kreatif dalam menemukan sumber-sumber penerimaan daerah yang dapat mendukung pembiayaan pengeluaran daerah. Undang-undang tentang Pemerintahan Daerah menetapkan pajak dan 3 biaya sebagai sumber pendapatan yang berasal dari dengan di daerah dan dapat dikembangkan sesuai dengan kondisi masing-masing daerah.

\section{Metode}

Penelitian penelitian ini menggunakan 2 metode, yaitu metode penelitian lapangan, yaitu pengamatan langsung di lokasi untuk melihat kondisi fisik. Metode Penelitian Perpustakaan. Metode pengumpulan data dengan membaca literatur yang berhubungan dengan objek penelitian. Manajemen parkir Pasar Pusat Kota Majene dalam mengumpulkan biaya parkir adalah proses kegiatan yang terdiri dari berbagai aspek yang saling mempengaruhi dengan harapan bahwa apa yang ingin mereka capai dapat dilakukan dengan baik sehingga perlu dianalisis berdasarkan aspek Perencanaan, implementasi dan pengawasan. Objek penelitian ini adalah upaya untuk meningkatkan dan memperbaiki sistem layanan pengelolaan parkir di pasar pusat Kota Majene. yang terkait erat 
dengan pemenuhan kebutuhan dasar masyarakat. Tahapan Implementasi Penelitian Tahapan penelitian meliputi: Persiapan instrumen penelitian, Pengambilan data dalam bentuk dokumentasi, wawancara dan studi literatur, Analisis Data melalui Metode Deskriptif Analisis data dilakukan secara deskriptif dengan memberikan deskripsi lokasi melalui identifikasi berbagai variabel termasuk analisis karakteristik parkir, dan penataan ruang parkir yang dapat memberikan rasa aman dan nyaman, Kesimpulan dan Saran, Hasil Desain

Metode penelitian dari penelitian ini:

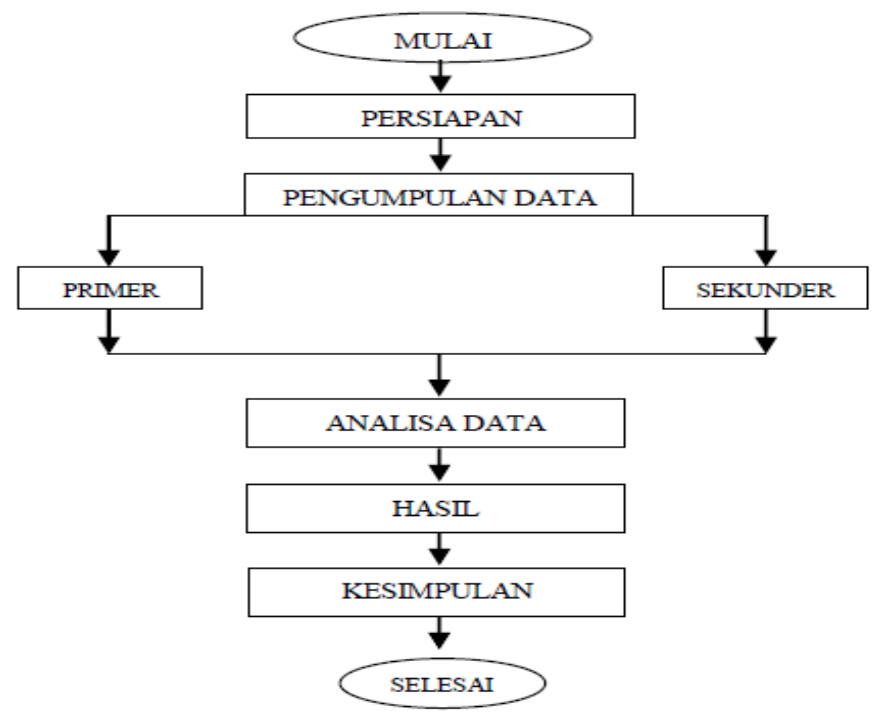

\section{Gambar 1. Alur penelitian}

\section{Pembahasan}

Penelitian dimulai dengan melakukan survei karakteristik parkir dalam 1 hari. Data dianalisis dengan menghitung jumlah kebutuhan parkir yang harus disediakan dari karakteristik parkir, kapasitas parkir, volume parkir, akumulasi parkir, durasi parkir, tingkat penggunaan parkir, dan indeks parkir. Penulis mengamati tempat parkir di pasar tengah Majene yang memiliki 3 titik parkir, yaitu area parkir area kanan, area depan, dan area dalam ,.

1. Parking Volume

Tabel 1. Persentase Volum Parkir

\begin{tabular}{crrrrr}
\hline \multirow{2}{*}{ Waktu } & \multicolumn{3}{c}{ Volume Parkir } & \multirow{2}{*}{ TOTAL } & \multirow{2}{*}{$\%$} \\
\cline { 2 - 4 } & \multicolumn{1}{c}{ Area I } & Area II & Area III & & \\
\hline 07:00-09:00 & 238 & 231 & 218 & 687 & 2,711 \\
09:00-11:00 & 943 & 949 & 900 & 2.792 & 11,019 \\
11:00-13:00 & 1.656 & 1.537 & 1.666 & 4.859 & 19,176 \\
13:00-15:00 & 2.672 & 2.446 & 2.611 & 7.729 & 30,502 \\
15:00-17:00 & 3.226 & 2.962 & 3.084 & 9.272 & 36,592 \\
\hline TOTAL & $\mathbf{8 . 7 3 5}$ & $\mathbf{8 . 1 2 5}$ & $\mathbf{8 . 4 7 9}$ & $\mathbf{2 5 . 3 3 9}$ & $\mathbf{1 0 0}$ \\
\hline
\end{tabular}


Berdasarkan tabel 1. Persentase volume parkir dalam penelitian ini adalah 25.339 dengan total ratarata rentang parkir 2 jam untuk 1 kendaraan bermotor dengan jam puncak volume parkir pada 10: 00-14: 00. Ini menunjukkan bahwa pada 10:00 pagi sampai 14:00 sore banyak pengunjung menggunakan waktu efisien mereka untuk mengunjungi pasar dalam hal kebutuhan sehari-hari mereka. Ini menunjukkan bahwa pada jam ini beban parkir di tempat parkir pasar sentral Majene berlebihan, sehingga masih menggunakan badan jalan untuk parkir.

2. Akumulasi Parkir

Tabel 2. Persentase Akumulasi Parkir

\begin{tabular}{crrrrr}
\hline \multirow{2}{*}{ Waktu } & \multicolumn{3}{c}{ Akumulasi Parkir } & \multirow{2}{*}{ TOTAL } & \multirow{2}{*}{$\%$} \\
\cline { 2 - 4 } & Area I & \multicolumn{1}{c}{ Area II } & Area III & & \\
\hline 07:00-09:00 & 131 & 149 & 117 & 397 & 7,032 \\
09:00-11:00 & 372 & 393 & 379 & 1.144 & 20,262 \\
11:00-13:00 & 513 & 395 & 648 & 1.556 & 27,559 \\
13:00-15:00 & 574 & 361 & 652 & 1.587 & 28,108 \\
15:00-17:00 & 371 & 214 & 377 & 962 & 17,039 \\
\hline TOTAL & $\mathbf{1 . 9 6 1}$ & $\mathbf{1 . 5 1 2}$ & $\mathbf{2 . 1 7 3}$ & $\mathbf{5 . 6 4 6}$ & $\mathbf{1 0 0}$ \\
\hline
\end{tabular}

Berdasarkan tabel penelitian 2, akumulasi parkir dalam penelitian ini adalah 5,646 dengan total rata-rata rentang parkir 2 jam untuk 1 kendaraan bermotor dengan jam puncak pukul 14: 00-16:00 dengan persentase $28 \%$. Ini menunjukkan bahwa pada jam ini beban parkir di tempat parkir pasar sentral Majene berlebihan, sehingga masih menggunakan badan jalan untuk parkir.

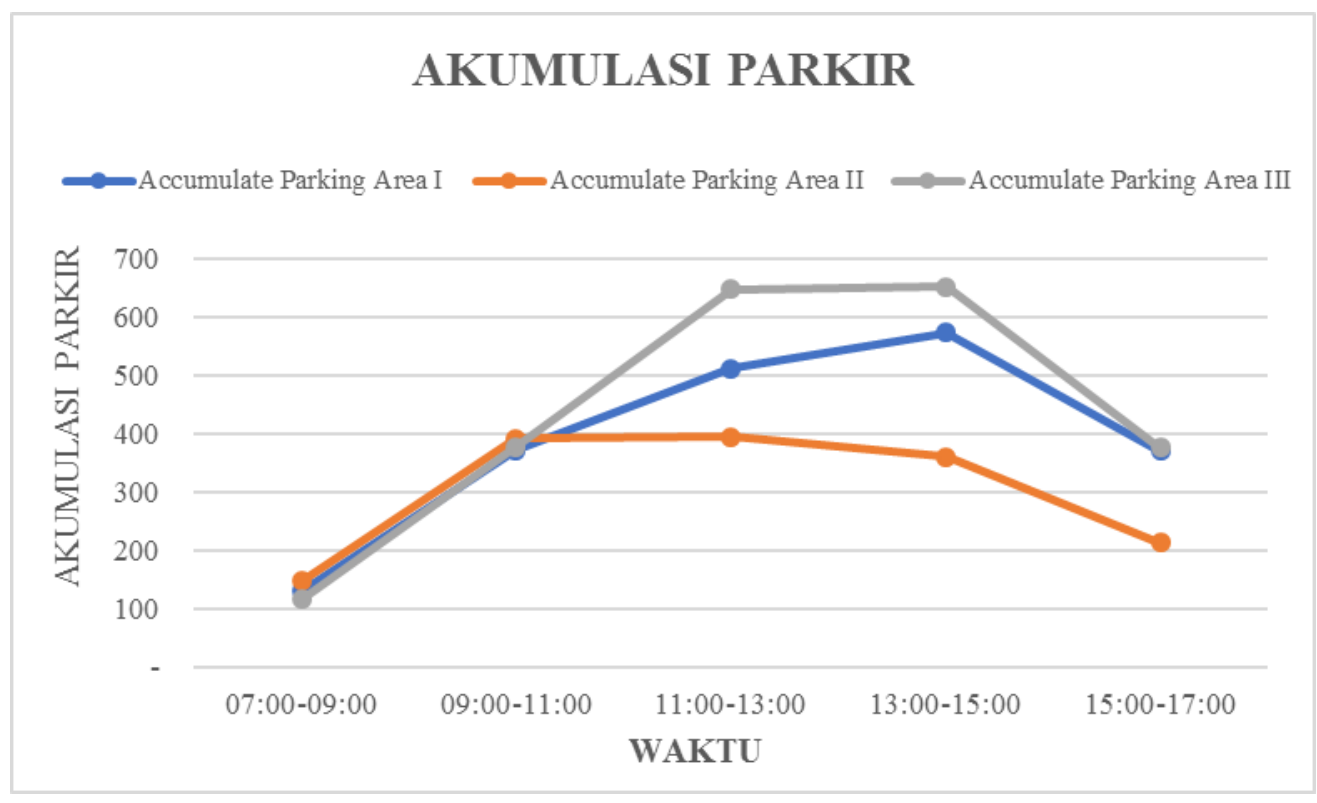

Gambar 2. Akumulasi Parkir

Berdasarkan Gambar 2, Akumulasi Parkir dalam penelitian ini dengan 3 area, dapat diketahui bahwa jam puncak Parkir Akumulasi pada jam 10:00 pagi sampai jam 14:00 sore.

\section{Kesimpulan}

Hasil penelitian diperoleh tempat parkir yang dibutuhkan sebesar 1.171 tempat parkir untuk kendaraan transportasi. Hasil penelitian ini menunjukkan karakteristik parkir di Pasar Sentral 
Majene yang meliputi volume, akumulasi dan kapasitas parkir diperoleh bahwa: 1). Volume parkir jam puncak pembeli/pengunjung terjadi pada jam 10:00 sampai 14:00; 2). Akumulasi parkir puncak tertinggi terjadi pada hari minggu pukul 11.00-15.00 oleh pembeli/ pengunjung dengan akumulasi; 3) Kapasitas parkir tertinggi pada jam 10:00 sampai jam 14:00. Bentuk yang cocok untuk kegiatan parkir di pasar sentral Majene adalah bentuk parkir $90^{\circ}$ dan bentuk parkir sudut dengan kemiringan $45^{\circ}$. Demikian juga untuk konsep pola parkir dan penataannya dapat dibedakan atas : 1) parkir untuk pengunjung harus mudah dicapai dan dekat dengan jalan sebagai akses utama; 2). Parkir pengelola harus dipisahkan dengan parkir pengunjung; 3) parkir hendaknya dapat dipisahkan berdasarkan jenis kendaraan.

\section{Saran}

Diharapkan agar Pemeliharaan parkir perlu dilakukan oleh pemerintah untuk memperhatikan ruang parkir di Pasar Sentral Kota Majene dan diharapkan menjadi perencanaan strategis dalam pengaturan dan retribusi pengaturan parkir di pasar pusat Kota Majene dan pengelolaan parkir

\section{Referensi}

Anonymous, 1999, "Pedoman Perencanaan Dan Pengoperasian Fasilitas Parkir", Direktorat Jendral Perhubungan Darat, Departemen Perhubungan

Anonymous, 1999, “Rekayasa Lalu Lintas", Direktorat Jendral Perhubungan Darat, Departemen Perhubungan.

Departemen Perhubungan, 1996, “Penyelenggaraan Fasilitas Parkir”, Direktorat Jendral Perhubungan Darat, Jakarta

Rosyidi, Muhammad, 2001 "Optimalisasi Penggunaan Lahan parkir di Pusat Matahari Mall Pekanbaru" Tugas Akhir, Jurusan Teknik sipil Universitas Islam Riau, Pekanbaru

Sujana, 1975, "Metode Statistika", Tarsito, Bandung.

Tamin, O.Z, 1997, "Perencanaan dan Permodelan Transportasi”, ITB, Bandung.

Lumba, P., \& Kunci, K. (n.d.). Analisis Kebutuhan Ruang Parkir di Pasar Muara Rumbai Analisa Kebutuhan Ruang Parkir Di Pasar Muara Rumbai Pasir Pengaraian, 121-126.

Jaya Wikrama, A. (2010). Analisis Karakteristik Dan Kebutuhan Parkir Di Pasar Kreneng. Jurnal Ilmiah Teknik Sipil, 14(2), 183-192.

Imam Mahmugi. (2017). "Evaluasi Kebutuhan Lahan Parkir pada Fakultas Teknik universitas Tanjungpura Pontianak" Skripsi Fakultas Teknik untan, Pontianak 